\title{
Self-efficacy and Differentiated Instruction: A Study among Malaysian School Teachers
}

\author{
Rosidah Ramli*, Nurahimah Mohd. Yusoff \\ School of Education and Modern Languages, Universiti Utara Malaysia, Malaysia \\ Received January 18, 2020; Revised February 18, 2020; Accepted February 24, 2020
}

Copyright $\bigcirc 2020$ by authors, all rights reserved. Authors agree that this article remains permanently open access under the terms of the Creative Commons Attribution License 4.0 International License

\begin{abstract}
The implementation of the mixed-ability classrooms in all secondary schools in Malaysia since 2019 calls for effective teaching strategies. Differentiated instruction is a teaching framework that takes into account the differences amongst students in creating learning opportunities for all. This study aimed to identify the level of teachers' self-efficacy and its significant influence over the differentiated instruction practices. Data was collected using an online questionnaire from 428 teachers teaching in the east coast zone of Malaysia. Two sets of inventories, namely Teachers' Sense of Efficacy Scale (TSES) and the differentiated instruction practice inventories, were adapted and modified to suit the purpose of this study. Findings showed that teachers' self-efficacy level is Excellent. The results of this study also proved the existence of a significant positive relationship between teachers' self-efficacy and teachers' practice of differentiated instruction, which in turn proved that teachers' self-efficacy has a major influence and can predict teachers' practice of differentiated instruction in the classroom. Therefore, it is hoped that the Ministry of Education Malaysia, the State Education Departments, the District Education Offices, as well as the schools can create a conducive climate for learning in schools, apart from providing practical and continuous professional development training to support teachers' self-efficacy towards further developing the practice of differentiated instruction in the classroom.
\end{abstract}

Keywords Differentiated Instruction, Teachers' Self-efficacy, Mixed-Ability Classroom, Malaysian Teachers

\section{Introduction}

Differentiated instruction is a teaching framework that takes into account the differences amongst students in creating learning opportunities for all [1]. It is a form of teaching which is responsive towards the unique needs of individual students through a teaching approach that combines multiple strategies [2]. Through the differentiated instruction approach, teachers make an effort to celebrate the differences amongst students in terms of their background knowledge, willingness to learn, language, learning style, and interest. This is done through responsive teaching that can fulfill the individual needs of the students [3]. Differentiated instruction is also known as a teaching approach with a student-centered focus which caters to varying levels of abilities, hence it is suitable for a classroom of mixed-ability students [4]. Although the curriculum content is standard and the same for all students, it is up to the teacher to modify the presentation of the curriculum content, to organize how it will be delivered, and to determine the type of assessment to be conducted. As there are differences between each student, the application of a single teaching method would not be the right choice and cannot cater to students' various needs in the classroom [5].

However, despite the changes and continual improvements in the education system, differentiated instruction has not often been put into practice, and no much difference has been seen in the teaching methods applied by teachers as compared to before [6], [7]. It is found that traditional teaching methods which are teacher-centered are still dominating instruction [8], [9]. Besides, teachers tend to implement direct instruction in their teaching and learning process too [10]. Even though teachers had received professional development training on differentiated instruction, this method of teaching is seldom implemented by them in the classroom due to the difficulties in implementing the differentiated instruction framework and opt to implement traditional approaches instead [11]-[15]. In fact, teachers still adopted traditional teaching styles despite knowing the advantages of the teaching approach and understanding the strategies and methods of its implementation.

The fact that differentiated instruction is not often put 
into practice, as reported, can be linked to an important factor, namely teachers' self-efficacy. Teachers' self-efficacy refers to the teacher's belief in his or her capabilities to plan and implement the action required to carry out complex and specific teaching tasks [25]. Several past studies have proven that there is a significant relationship between teachers' self-efficacy and teachers' behavior in teaching. Although teachers realize that each student has their own needs and learn in different ways, not all teachers are determined to implement differentiated instruction [28]. Although they cognitively understand every strategy and method in the implementation of differentiated instruction, teachers may not translate this knowledge into their teaching practices in the classroom. There are a handful of teachers who lack confidence in their knowledge and skills, making it difficult for them to tailor their teaching according to their students' particular needs. Should this be explained in terms of the concept of teachers' self-efficacy, teachers having low self-confidence perceive that they do not have the time to plan lessons or they feel that what has been planned will fail. In fact, teachers may regard the task of implementing differentiated instruction as being very difficult to do.

Past studies clearly indicate that differentiated instruction has not been widely implemented in the classroom and thus may lead to negative consequences. As stated by Tomlinson [16], if teachers ignore different needs of students, they will be likely to teach concepts or skills that have already mastered by the gifted students and thus no learning will occur. On the other hand, if the learning is too difficult, students will be disadvantaged and may begin to have learning difficulties and demotivated.

Therefore, to identify the influence of teachers' self-efficacy towards the practice of differentiated instruction in the classroom, this research is conducted to

1. Identify the level of teachers' self-efficacy based on the aspects of (i) classroom management, (ii) student management and (iii) teaching strategy management.

2. Identify the level of differentiated instruction practiced by teachers based on the aspects of (i) identifying the differences amongst students, (ii) learning environment, (iii) practice of differentiated instruction (learning content), (iv) practice of differentiated instruction (learning process), (v) practice of differentiated instruction (learning product) and (vi) practice of differentiated instruction (assessment).

3. Identify the extent of influence of teachers' self-efficacy towards the practice of differentiated instruction by teachers.

\section{Literature review}

\subsection{Differentiated Instruction}

Differentiated instruction is not a new concept and has been used for a very long time in the guise of 'mixed-ability teaching'. Differentiated instruction is a model of teaching which requires teachers to practice flexible approaches in their delivery of instruction by adjusting the curriculum and instruction to suit students' needs instead of expecting them to adapt to the curriculum. In fact, differentiated instruction makes it possible for students with different levels of ability to sit together in one classroom and receive the appropriate learning opportunities following their individual levels of ability.

For effective differentiated instruction, Tomlinson [16]-[18] and Tomlinson et al. [19] identified five teaching and learning elements for teachers to differentiate.

1) Content. Knowledge and skills that students should learn and master within the necessary time or how students gain access to information needed. For example; curriculum compacting, concept-based learning or varying materials, resources and guidance for students.

2) Process. How the curriculum content is delivered to students or approaches to activities that help students to make sense or master the content. For example; individual tasks, learning methods or varying the time and resources.

3) Products. How students show what they know, understand and can do. Teachers need to offer students several choices to demonstrate their learning.

4) Environment. The climate of the classroom which is conducive and safe to promote learning.

5) Assessment. Pre-assessment to assess students' readiness and ability so as teachers can adapt and modify learning. High-quality assessment is a tool to guide students in learning.

Effective and consistent implementation of differentiated instruction has been proven to have a positive impact on all groups of students at every level of schooling, from the bright and intelligent students to those with learning difficulties [20]-[24].

\subsection{Teachers' Self-efficacy}

Teachers' self-efficacy also refers to the teachers' determination to influence their students' achievements [25], [26]. Social Cognitive Theory by Bandura [27] is a theory based on which the teacher's self-efficacy theory is derived. Bandura detailed out how self-efficacy refers to an individual's ability and skill to plan and carry out what has been planned. An individual must possess a high level of optimism so that a particular task can be carried out willingly and confidently. Bandura perceived teachers' self-efficacy as a form of self-efficacy which is centered on the ability and determination of teachers to free themselves from difficulties when facing with problems or 
failures.

Studies by Dixon, Yssel, McConnell and Hardin [11], De Neve, Devos and Tuytens [14] and Wertheim and Leyser [29] have proven that highly efficacious teachers incline to practice a high level of differentiated instruction. New teachers with high self-efficacy are also found to adapt their teaching practices better and often determined to find the most suitable strategy to implement differentiated instruction every time they met failure [14]. Additionally, teachers' self-efficacy is also the main factor that drives teachers' motivation to involve themselves in professional development related to differentiated instruction [30]. Self-efficacy also helps teachers have more open and positive attitude towards differentiated instruction, and develop a high level of willingness to implement it [31], [32].

Clearly, teachers' self-efficacy is vital in the implementation of differentiated instruction among teachers. Teachers must have a high level of self-efficacy in order to be able to effectively translate their knowledge and skills into differentiated instruction practices. The factor of self-efficacy is influential in the early phases of the implementation of differentiated instruction by teachers. With continous practice, teachers gain more understanding of differentiated instruction and master the required skills to implement it.

\section{Materials and Methods}

\subsection{Research Design}

A cross-sectional research design was utilized in this study by collecting data from a population at one specific point in time. This design enabled the researcher to use self-reported survey to collect data on teachers' self-efficacy and see how it might correlate to teachers' differentiated instruction practices.

\subsection{Sample}

Data was collected from 428 secondary school teachers selected using simple random sampling from 424 schools across the east coast zone of Malaysia namely the states of Kelantan, Terengganu and Pahang. Of the 428 teachers, $119(27.8 \%)$ were male and $309(72.2 \%)$ were female. Moreover, $7(1.6 \%)$ of the teachers were under $30 ; 122$ (28.5\%) were between 31 to 40 years old; 177 (41.4\%) were between 41 to 50 years old; and, $122(28 \%)$ were over 50 years old. Of the 428 teachers in this study, 10 $(2.3 \%)$ had been teaching for less than 5 years; 49 (11.4\%) had been teaching for 6 to 10 years; $168(39.3 \%)$ had been teaching for 11 to 20 years; $178(41.6 \%)$ had been teaching for 21 to 30 years; and, $23(5.4 \%)$ had been teaching for over 30 years.

\subsection{Instrumentation}

The survey used in this study consisting of 3 parts; demographic information, Teacher Sense of Efficacy Scale (TSES) inventory by Tschannen-Moran and Hoy [25] and differentiated instruction practices inventory by Santangelo and Tomlinson [33]. The translated and modified version of TSES inventory included 12 statements used to measure teachers' self-efficacy in (i) classroom management (4 items); (ii) students management (4 items); and, teaching strategy management (4 items). Meanwhile, the translated and modified version of Santangelo and Tomlinson's teachers differentiated instruction practices inventory included 39 statement was used to measure teachers' implementation of differentiated instruction in (i) identifying students' differences (6 items); (ii) learning environment (6 items); (iii) learning content (9 items); (iv) learning process ( 7 items); (v) learning products (4 items); and, assessment (7 items). Both inventories used a ten-point interval Likert scale varying from 1 (strongly disagree) to 10 (strongly agree).

Table 1 shows that all dimensions of both constructs meet the minimal reliability coefficient of 0.70 as suggested by Nunnaly [34].

Table 1. Cronbach's Alpha Reliability of the survey instrument

\begin{tabular}{|c|c|c|c|}
\hline Constructs & Dimensions & No of items & Cronbach's Alpha Reliability \\
\hline Teachers' self-efficacy & Classroom management & 4 & 0.92 \\
\hline & Students management & 4 & 0.90 \\
\hline & Teaching strategy management & 4 & 0.90 \\
\hline & & 12 & 0.96 \\
\hline Teachers' differentiated instruction practices & Identifying students' differences & 6 & 0.95 \\
\hline & Learning environment & 6 & 0.94 \\
\hline & Learning content & 9 & 0.96 \\
\hline & Learning process & 7 & 0.92 \\
\hline & Learning product & 4 & 0.90 \\
\hline & Assessment & 7 & 0.94 \\
\hline
\end{tabular}




\subsection{Procedure}

For this study, data was collected online using Surveymonkey ${ }^{\circledR}$. Once approval was gained from the Education Planning and Research Division (EPRD), Ministry of Education (MOE) Malaysia, an email containing the link to the survey was sent to all schools which teachers selected as sample for the study. The survey was opened for two weeks and at the end of the first week, another email was sent to remind teachers of the survey deadline.

\subsection{Analysis}

Factor analysis was performed on both TSES and differentiated instruction practices inventory to confirm the factors of each construct. Later, a Pearson-correlation test was carried out to see any relationship between teachers' self-efficacy and teachers' differentiated instruction practices followed by simple linear regression to identify teachers' self-efficacy influences over teachers' differentiated instruction practices.

\section{Findings}

\subsection{Factor Analysis}

Using principal component analysis, factor analysis was done to both inventories. For TSES, all of the items loaded onto 3 factors, namely classroom management, students' management and teaching strategy management as shown in Table 2.

Table 2. Factor item loadings for TSES inventory

\begin{tabular}{|c|c|c|c|}
\hline & \multicolumn{3}{|c|}{ Dimension of TSES } \\
\hline Item & $\begin{array}{c}\text { Classroom } \\
\text { management }\end{array}$ & $\begin{array}{c}\text { Students' } \\
\text { management }\end{array}$ & $\begin{array}{c}\text { Teaching strategy } \\
\text { management }\end{array}$ \\
\hline 1 & .741 & & \\
\hline 2 & .781 & & \\
\hline 3 & .766 & & \\
\hline 4 & .648 & & \\
\hline 5 & & .672 & \\
\hline 6 & & .795 & \\
\hline 7 & & .638 & \\
\hline 8 & & .724 & .715 \\
\hline 9 & & & .685 \\
\hline 10 & & & .739 \\
\hline 11 & & & \\
\hline 12 & & & \\
\hline
\end{tabular}

"Extraction Method: Principal Component Analysis.

Rotation Method: Varimax with Kaiser Normalization."

For teachers' differentiated instruction practices, all of the items loaded onto six factors, namely identifying students' differences, learning environment, learning content, learning process, learning product and assessment as shown in Table 3.

Table 3. Factor item loadings for teachers' differentiated instruction practices inventory

\begin{tabular}{|c|c|c|c|c|c|c|}
\hline \multicolumn{7}{|c|}{ Dimensions of teachers' differentiated instruction practices } \\
\hline Item & $\begin{array}{c}\text { Identifying students' } \\
\text { differences }\end{array}$ & $\begin{array}{c}\text { Learning } \\
\text { environment }\end{array}$ & Learning content & Learning process & Learning product & Assessment \\
\hline 1 & .737 & & & & & \\
\hline 2 & .727 & & & & & \\
\hline 3 & .745 & & & & & \\
\hline 4 & .703 & & & & & \\
\hline 5 & .631 & & & & & \\
\hline 6 & .658 & & & & & \\
\hline 7 & & .613 & & & & \\
\hline 8 & & .762 & & & & \\
\hline 9 & & .686 & & & & \\
\hline 10 & & .761 & & & & \\
\hline 11 & & .733 & & & & \\
\hline 12 & & .612 & & & & \\
\hline 13 & & & .606 & & & \\
\hline 14 & & & .606 & & & \\
\hline 15 & & & .629 & & & \\
\hline 16 & & & .697 & & & \\
\hline 17 & & & .687 & & & \\
\hline 18 & & & .620 & & & \\
\hline
\end{tabular}


Table 3 Continued

\begin{tabular}{|c|c|c|c|c|}
\hline 19 & .625 & & & \\
\hline 20 & .616 & & & \\
\hline 21 & .604 & & & \\
\hline 22 & & .603 & & \\
\hline 23 & & .634 & & \\
\hline 24 & & .655 & & \\
\hline 25 & & .694 & & \\
\hline 26 & & .721 & & \\
\hline 27 & & .699 & & \\
\hline 28 & & .681 & & \\
\hline 29 & & & .696 & \\
\hline 30 & & & .811 & \\
\hline 31 & & & .722 & \\
\hline 32 & & & .649 & \\
\hline 33 & & & & .683 \\
\hline 34 & & & & .610 \\
\hline 35 & & & & .605 \\
\hline 36 & & & & .680 \\
\hline 37 & & & & .660 \\
\hline 38 & & & & .748 \\
\hline 39 & & & & .685 \\
\hline
\end{tabular}

"Extraction Method: Principal Component Analysis.

Rotation Method: Varimax with Kaiser Normalization."

\subsection{Level of Teachers' Self-efficacy}

To measure the level of self-efficacy and teachers' practice of differentiated instruction, the mean score interpretation table (Table 4) is referred.

Table 4. Mean score interpretation table

\begin{tabular}{|c|c|}
\hline Mean score & Mean score interpretation \\
\hline $1.00-2.50$ & Low \\
\hline $2.51-4.00$ & Moderate low \\
\hline $4.01-5.50$ & Moderate \\
\hline $5.51-7.00$ & Moderate good \\
\hline $7.01-8.50$ & Good \\
\hline $8.51-1.00$ & Excellent \\
\hline
\end{tabular}

Table 5. Mean score of teachers' self-efficacy construct

\begin{tabular}{|c|c|}
\hline Teachers' self-efficacy dimensions & Mean \\
\hline Classroom management & 8.62 \\
\hline Student management & 8.81 \\
\hline Teaching strategy management & 8.51 \\
\hline Overall & 8.65 \\
\hline
\end{tabular}

To answer the first research question, means were calculated from the response on the TSES inventory. Based on the table of mean score interpretation, the level of self-efficacy amongst teachers is Excellent. The highest average mean obtained through the dimension of teacher self-efficacy in the management of classroom is 8.81 , followed by the dimension of teacher self-efficacy in classroom management at 8.62 and the dimension of teacher self-efficacy in teaching strategy at 8.51, (Table $5)$.

\subsection{Level of Teachers' Differentiated Instruction Practices}

Table 6. Mean score of teachers' practice of differentiated instruction

\begin{tabular}{|l|l|}
\hline Teachers' practice of differentiated instruction & Mean \\
\hline Identifying differences amongst students & 8.25 \\
\hline Learning environment & 8.80 \\
\hline Practice of differentiated instruction (learning content) & 8.31 \\
\hline Practice of differentiated instruction (learning process) & 8.00 \\
\hline Practice of differentiated instruction (learning product) & 8.14 \\
\hline Practice of differentiated instruction (assessment) & 8.15 \\
\hline Overall & 8.28 \\
\hline
\end{tabular}

To answer the second research question, means were calculated from the response on teachers' differentiated instruction practices inventory. Based on the table of mean score interpretation, the level of differentiated instruction practices amongst teachers is Good. The 
highest average mean obtained for the dimension of learning environment is 8.80 , while the lowest average mean obtained for the dimension of differentiated instruction practice through students' learning process is 8.00 (Table 6).

\subsection{The Influence of Teachers' Self-efficacy on Teachers' Practice of Differentiated Instruction}

Table 7. Pearson Correlation between the constructs of teachers' self-efficacy (TSE) and teachers' practice of differentiated instruction (TPDI)

\begin{tabular}{|c|c|c|c|}
\hline \multicolumn{2}{|c|}{} & TSES & TPDI \\
\hline \multirow{3}{*}{ TSES } & Pearson Correlation & 1 & $.830^{* *}$ \\
\cline { 2 - 4 } & Sig. (2-tailed) & & .000 \\
\cline { 2 - 4 } & $\mathrm{N}$ & 428 & 428 \\
\hline \multirow{3}{*}{ TPDI } & Pearson Correlation & $.830^{* *}$ & 1 \\
\cline { 2 - 4 } & Sig. (2-tailed) & .000 & \\
\cline { 2 - 4 } & $\mathrm{N}$ & 428 & 428 \\
\hline **. P<.05 (2-tailed) & & \multicolumn{3}{|l}{} \\
\hline
\end{tabular}

To investigate the effect of self-efficacy on differentiated instruction practices and answer research question 3, a correlation test and simple linear regression were conducted. The Pearson correlation shows that teachers' self-efficacy is significantly correlated to teachers' differentiated instruction practices. As seen in Table 7, there is a strong positive correlation between teachers' self-efficacy and teachers' differentiated instruction practices, $(\mathrm{r}=.83, \mathrm{p}<.05)$ showing that the higher teachers' self-efficacy is, the more they will likely to implement differentiated instruction and vice versa.

The finding of the ANOVA test shows that teachers' self-efficacy is a significant contributor towards the practice of differentiated instruction, where $F(1,426)=$ $941.80, p=.00(p<.05)$ shows that the regression model is linear. In this analysis, $\mathrm{R}^{2}=0.689$ shows that about $68.9 \%$ of total variation in teachers' differentiated instruction practices is explained by teachers' self-efficacy. The finding proves that at $68.9 \%$, teachers' self-efficacy greatly contributes to the prediction of differentiated instruction practices by teachers (Table 8 ).

Table 8. Linear regression between the constructs of teachers' self-efficacy and teachers' practice of differentiated instruction

\begin{tabular}{|c|c|c|c|c|c|c|c|c|c|}
\hline \multicolumn{10}{|c|}{ Model Summary ${ }^{\mathrm{b}}$} \\
\hline \multirow{2}{*}{ Model } & \multirow{2}{*}{$\mathrm{R}$} & \multirow{2}{*}{ R Square } & \multirow{2}{*}{$\begin{array}{l}\text { Adjusted R } \\
\text { Square }\end{array}$} & \multirow{2}{*}{$\begin{array}{c}\text { Std. Error of the } \\
\text { Estimate }\end{array}$} & \multicolumn{5}{|c|}{ Change Statistics } \\
\hline & & & & & R Square Change & F Change & df1 & df 2 & Sig. F Change \\
\hline 1 & $.830^{\mathrm{a}}$ & .689 & .688 & .53721 & .689 & 941.80 & 1 & 426 & .000 \\
\hline \multicolumn{10}{|c|}{ a. Predictors: (Constant), TSE } \\
\hline \multicolumn{10}{|c|}{ b. Dependent Variable: TPDI } \\
\hline
\end{tabular}

\begin{tabular}{|c|c|c|c|c|c|c|}
\hline \multicolumn{7}{|c|}{ ANOVA $^{\mathrm{a}}$} \\
\hline \multirow{3}{*}{1} & Model & Sum of Squares & $\mathrm{df}$ & Mean Square & F & Sig. \\
\cline { 2 - 7 } & Regression & 271.803 & 1 & 271.803 & 941.808 & $.000^{\mathrm{b}}$ \\
\cline { 2 - 7 } & Residual & 122.942 & 426 & .289 & & \\
\hline
\end{tabular}

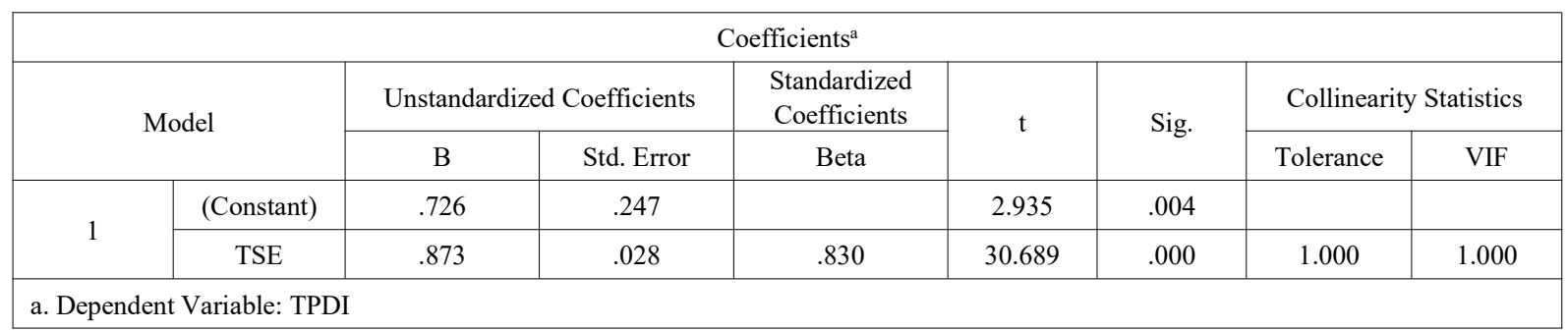




\section{Discussion}

The present study investigated the influence of teachers' self-efficacy on teachers' differentiated instruction practices. The findings showed that teachers have a high level of self-efficacy as reported in the previous research by Rahimah Jamaluddin, Rosini Abu, Abdullah Mat Rashid and Habsah Ismail [35], Awanis Mohd, Ainunmadiah Mohd Nawawi and Siti Noor Ismail [36] and Noornajihan Jaafar and Ab Halim Tamuri [37]. The findings also showed that in overall, teachers' practice of differentiated instruction is at a good level. This finding contradicted with the findings reported in previous differentiated instruction related studies by Dixon et al. [11], Gilson, Little and Ruegg [12], Mohd Hasrul Kamarulzaman, Hazita Azman and Azizah Mohd Zahidi [13], De Neve, Devos and Tuytens [14], Butt and Kausar [38] and Kaur [39]. One possible explanation for this finding is that teachers acknowledge that differentiated instruction is the only method to cater to students' different needs and level in a mixed-ability classroom.

This is also enhanced by teachers' high level of self-efficacy, which helps them to respond positively to difficulties they face especially when differentiated instruction approach is a new concept to teachers and not emphasized by the MOE until recently with the implementation of Malaysian Education Blueprint 2013-2025 that introduced the $21^{\text {st }}$ century teaching and learning [39]. With the abolishment of class streaming and replacement by a mixed-ability classroom, teachers realize the need for an effective teaching strategy that caters to the needs of all students compared to the teaching methods practiced before.

The findings of this study offer contribution to the field of education as it sheds light on the level of differentiated instruction implemented in Malaysia classroom as research on differentiated instruction in Malaysia is limited especially concerning the secondary school of Malaysia. This study is important as a first step in understanding teachers' practices of differentiated instruction in a newly implemented mixed-ability classroom, a new concept to Malaysia educational system.

\section{Recommendation}

Differentiated instruction practices starts with the willingness and determination to change the way of teaching in order to improve students' performance. Even though differentiated instruction seems to promise good impact on students learning and achievement but teachers will likely not to implement it in their teaching and learning until they have higher self-efficacy. The Ministry of Education, the State Education Departments and the District Education Offices should identify appropriate and effective continuous professional development to empower and increase teachers' self-efficacy and ultimately improve differentiated instruction practices to a higher level. Practical and effective continuous professional development is crucial to avoid counterproductive when teachers having varying levels of experience have to sit through the same topic over and over. A better way is to run training session where teachers can share their experience especially on the teaching strategy management and lead to a culture of working together to improve self-efficacy and differentiated instruction practices as well.

\section{REFERENCES}

[1] C. A. Tomlinson and M. B. Imbeau, Leading a differentiated classroom. Alexandria, Virginia USA: ASCD, 2010.

[2] S. Watts-Taffe et al., "Differentiated instruction: Making informed teacher decisions," Read. Teach, vol. 66, no. 4, pp. 303-314, 2012.

[3] C. A. Tomlinson and M. I. Kalbfleisch, "Teach me, teach my brain: A Call for differentiated classrooms," Educ. Leadersh., vol. 56, no. 3, pp. 52-55, 1998, doi: 10.1146/annurev.immunol.19.1.475.

[4] S. Winebrenner, Teaching gifted kids in the regular classroom. Minneapolis, MN: Free Spirit Publishing Inc, 2001.

[5] J. M. Firmender, S. M. Reis, and S. M. Sweeny, "Reading comprehension and fluency levels ranges across diverse classrooms: The need for differentiated reading instruction and content," Gift. Child Q., vol. 57, no. 1, pp. 3-14, 2013, doi: 10.1177/0016986212460084.

[6] M. Bauml, "Beginning primary teachers experiences with curriculum guides and pacing calendars for math and science instruction," J. Res. Child. Educ., vol. 29, no. 3, pp. 390-409, 2015, doi: 10.1080/02568543.2015.1040565.

[7] A. Hargreaves and I. Goodson, "Educational change over time? The sustainability and nonsustainability of three decades of secondary school change and continuity," Educ. Adm. Q., vol. 42, no. 1, pp. 3-41, 2006, doi:10.1177/0013161X05277975.

[8] Salmiza Saleh and Afik Aziz, "Teaching practices among secondary school teachers in Malaysia," Int. Proc. Econ. Dev. Res., vol. 47, no. 14, pp. 63-67, 2012, doi: 10.7763/IPEDR.2012.V47.14.

[9] Suriati Salleh and Nurahimah Mohd. Yusoff, "Teachers' attitudes and beliefs towards the use of student-centred leaning in English language classes," Proc. ICECRS, vol. 1, no. 1, pp. 327-334, 2017, doi: 10.21070/picecrs.v1i1.501.

[10] Cathrine Masingan and Sabariah Sharif, "Pedagogical Content Knowledge (PCK) of Out-of-Field Teacher in Design and Technology (RBT) Subject in Secondary School," Malaysian J. Soc. Sci. Humanit., vol. 4, no. 6, pp. 64-71, 2019.

[11] F. A. Dixon, N. Yssel, J. M. McConnell, and T. Hardin, 
"Differentiated instruction, professional development, and teacher efficacy," J. Educ. Gift., vol. 37, no. 2, pp. 111-127, 2014, doi: 10.1177/0162353214529042.

[12] C. M. Gilson, C. A. Little, A. N. Ruegg, and M. Bruce-davis, "An investigation of elementary teachers' use of follow-up questions for students at different reading levels," J. Adv. Acad., vol. 25, no. 2, pp. 101-128, 2014 , doi: $10.1177 / 1932202 X 14532257$.

[13] Mohd Hasrul Kamarulzaman, Hazita Azman, and Azizah Mohd Zahidi, "Differentiated instruction strategies in English language teaching for gifted students," J. Appl. Environ. Biol. Sci., vol. 7, pp. 78-90, 2017.

[14] D. De Neve, G. Devos, and M. Tuytens, "The importance of job resources and self-efficacy for beginning teachers' professional learning in differentiated instruction," Teach. Teach. Educ., vol. 47, pp. 30-41, 2015, doi: 10.1016/j.tate.2014.12.003.

[15] D. Powell, H. J. Higgins, R. Aram, and A. Freed, "Impact of No Child Left Behind on curriculum and instruction in rural schools," Rural Educ., vol. 31, no. 1, pp. 19-28, 2009.

[16] C. A. Tomlinson, "Quality curriculum and instruction for highly able students," Theory Pract., vol. 44, no. 2, pp. 160-166, 2005, doi: 10.1207/s15430421tip4402_10.

[17] C. A. Tomlinson, "Maping a route toward Differentiated instruction," Educ. Leadersh., vol. 57, no. 1, pp. 12-16, 1999, doi: 10.1016/0040-6031(83)80143-9.

[18] C. A. Tomlinson, "Deciding to teach them all," Educ. Leadersh., vol. 61, no. 2, pp. 6-11, 2003.

[19] C. A. Tomlinson et al., "Differentiating instruction in response to student readiness, interest, and learning profile in academically diverse classrooms: A review of literature. Introduction: A rationale for differentiating instruction," J. Educ. Gift., vol. 27, no. 2/3, pp. 119-145, 2003.

[20] L. McQuarrie, P. McRae, and H. Stack-Cutler, "Differentiated Instruction Provincial Research Review: Choice, complexity and creativity," 2008.

[21] S. M. Reis, D. B. McCoach, C. A. Little, L. M. Muller, and R. B. Kaniskan, "The effects of differentiated instruction and enrichment pedagogy on reading achievement in five elementary schools," Am. Educ. Res. J., vol. 48, no. 2, pp. 462-501, 2011, doi: 10.3102/0002831210382891.

[22] Mohd Fadzil Kamarudin, Mohd Hasrul Kamarulzaman, Mohd Saidun Aznin Mohd Sharif, Mior Muhamad Saiful Nizan Saali, and Muhammad Zaim Esrati, "The impact of differentiated instructions on the motivation and achievements of gifted students in Mathematics," in The 3rd International Conference on Education in Muslim Society (ICEMS) 2017, 2017, pp. 1-6.

[23] C. Tieso, "The effects of grouping and curricular practices on intermediate students' Math Achievement," J. Educ. Gift., vol. 29, no. 1, pp. 60-89, 2002, doi: Article.

[24] M. Zafiri, A. Konstantinidou, and V. Pliogou, "The application of differentiated instruction in reading and writing to a boy with autism in early childhood education. A case study," Univers. J. Educ. Res., vol. 7, no. 12, pp. 2609-2626, 2019, doi: 10.13189/ujer.2019.071208.
[25] M. Tschannen-Moran, A. W. Hoy, and W. K. Hoy, "Teacher efficacy: Its meaning and measure," Rev. Educ. Res., vol. 68, no. 2, pp. 202-248, 1998.

[26] A. Bandura, "Self-efficacy: Toward a unifying theory of behavioral change," Psychol. Rev., vol. 84, no. 2, pp. 191-215, 1977, doi: 10.1037/0033-295X.84.2.191.

[27] A. Bandura, "Social cognitive theory of personality," in Handbook of personality: Theory and research 2nd ed., L. Pervin and O. John, Eds. 1999, pp. 154-196.

[28] P. S. George, "A rationale for differentiating instruction in the regular classroom," Theory Pract., vol. 44, no. 3, pp. 185-193, 2005, doi: 10.1207/s15430421tip4403 2.

[29] C. Wertheim and Y. Leyser, "Efficacy beliefs, background variables, and differentiated instruction of Israeli prospective teachers," J. Educ. Res., vol. 96, no. 1, pp. 54-63, 2002, doi: 10.1080/00220670209598791.

[30] E. E. J. Thoonen, P. J. C. Sleegers, F. J. Oort, T. T. D. Peetsma, and F. P. Geijsel, "How to improve teaching practices: The role of teacher motivation, organizational factors, and leadership practices," Educ. Adm. Q., vol. 47, no. 3, pp. 496-536, 2011, doi: $10.1177 / 0013161 \mathrm{X} 11400185$.

[31] R. M. Allinder, "The Relationship Between Efficacy and the Instructional Practices of Special Education Teachers and Consultants,” Teach. Educ. Spec. Educ. J. Teach. Educ. Div. Counc. Except. Child, vol. 17, no. 2, pp. 86-95, 1994 , doi: $10.1177 / 088840649401700203$.

[32] W. J. G. Evers, A. Brouwers, and W. Tomic, "Burnout and self-efficacy: A study on teachers' beliefs when implementing an innovative educational system in the Netherlands," Br. J. Educ. Psychol., vol. 72, no. 2, pp. 227-243, 2002, doi: 10.1348/000709902158865.

[33] T. Santangelo and C. A. Tomlinson, "Teacher educators' perceptions and use of differentiated instruction practices: An exploratory investigation," Action Teach. Educ., vol. 34, no. 4, pp. 309-327, 2012, doi: $10.1080 / 01626620.2012 .717032$.

[34] Nunnaly 1978, "Coefficient alpha: Interpret with caution," Eur. J. Psychol., 2013, doi: 10.5964/ejop.v9i4.653.

[35] H. Jamaluddin, Rahimah, Abu, Rosini, Mat Rashid, Abdullah \& Ismail, "Tahap Efikasi Kendiri Guru Dalam Melaksanakan Pengajaran Kekeluargaan," J. Sains Humanika, vol. 2020, no. 2010, pp. 135-144, 2014, doi: 10.11113/SH.V2N1.389.

[36] Awanis Mohd, Ainunmadiah Mohd Nawawi, and Siti Noor Ismail, "Tahap efikasi guru Dan hubungannya dengan pencapaian sekolah di sekolah -sekolah menengah daerah Bachok," Proceeding ICECRS Int. Semin. Gener. Knowl. Through Res., vol. 1, no. October, pp. 1-11, 2016, doi: 10.21070/picecrs.v1i1.500.

[37] Noornajihan Jaafar and Ab Halim Tamuri, "Hubungan Antara Efikasi Kendiri Dengan Kualiti Guru Pendidikan Islam Sekolah Menengah Kebangsaan Malaysia,” J. Islam. Arab. Educ., 2013.

[38] M. Butt and S. Kausar, "A Comparative Study of Using Differentiated Instructions of Public and Private School Teachers," Malaysian J. Distance Educ. 12(1), 105?124, 
vol. 12, no. 1, pp. 105-124, 2010.

[39] M. Kaur, "To recognise, realise and differentiate the learning needs of students," Pertanika J. Soc. Sci. Humanit., vol. 25, no. 2, pp. 503-510, 2017. 